\title{
A Bird's Eye View: More-Than-Human Migrations
}

\author{
Carol M. Lee \\ University of Ottawa \\ clee185@uottawa.ca
}

\begin{abstract}
With a focus on bird migrations, this essay seeks to understand Derrida's (2000) concept of hospitality and its corollary, the relationship between guest and host, in the more-than-human world. The essay begins by considering the implications of migratory movement on the morethan-human "hosts" residing in both summer and winter habitats. It then considers how, depending on one's perspective, migratory bird populations might be considered both guests and hosts simultaneously in/of two locals, and yet also foreigners as they move out, through, and into various territories. I use this three-part paradox to tease out subtle distinctions toward an understanding of hospitality in relation to both humans and more-than-human contexts. This essay also draws on key related concepts from Deleuze and Guattari (1987) and uses Barad's (2007) diffractive methodology to understand the intersection of hospitality and migration in more-than-human and human landscapes.
\end{abstract}

Keywords: Hospitality; nomad; migration; Derrida; Deleuze; Guattari; diffractive

\section{Introduction}

An act of hospitality can only be poetic. (Derrida, 2000, p. 1)

Nomadic waves or flows of deterritorialization go from the central layer to the periphery, then from the new center to the new periphery, falling back to the old center and launching forth to the new. (Deleuze \& Guattari, 1987, p. 39)

It is mid-March. Many birds are returning. The ones who never left are more active. Certainly, they are more vocal. Snow has pulled away from the edges of the deck, and the plants that spent the winter inside with me are leaning into the glass of the patio door, eager it seems, like me, to get out again. This year, winter was unexpectedly short and mild. Hospitable, some might say. Looking outside at the leafless arbor, listening to, as much as seeing the creatures dwelling there, I ponder Derrida's (2000) ideas about hospitality being poetic, and his conceptualization of hospitality as a question of "where." Imagining the fiddleheads yet to

\footnotetext{
${ }^{1}$ I draw on Dufourmantelle, Derrida's co-author, to summarize Derrida's position concerning the question of where. She says, "I think this geography leads throughout the seminar to the revelation of the question 'Where?' as being the question of man. A question which, like that of the Sphinx, is addressed to a man on the move, who has no other place of his own than that of being on the way, bound for a destination that is unknown to him, but precedes him with its shadow" (Derrida \& Dufourmantelle, 2000, p. 52).
}

Cultural and Pedagogical Inquiry, Fall 2020, 12(2), pp. 107-118

ISSN 1916-3460 (C) 2020 University of Alberta

http://ejournals.library.ualberta.ca/index.php/cpi/index 
come, under the trees and under the snow forming fern rhizomes ${ }^{2}$, I wonder if location (where) and Derrida's concept of the host and foreigner, although they are concepts developed to explain human hospitality, can be applied to more-than-human hospitality and if so, are they congruent with Deleuze and Guattari's (1987) constructions of the nomad, de/re-territorializing lines of flight, and disruptions of conventional thought expressed as war machines. What might their interplay be(come)?

This essay is written in the style of a nomadic exercise. While my exercise was completed prior to this writing, my aim in using this writing style is to show, expose if you will, how thought exercises develop in nonlinear ways, not as a line of argument. Thoughts jump around and make unexpected associations. At least mine do. It is for this reason that I use a diffractive methodology, as described by Barad (2012), to both structure my thought experiment/ exercise and to allow my thoughts the latitude to de/re-territorialize and move in multiple directions. For readers who are more comfortable with a linear argumentative writing style, may I suggest reading my conclusion first. There, I frame the movement of my exercise as an argument and as such it may provide context and structure for reading the rest of this essay.

$* \quad * \quad *$

A diffractive methodology aims to bring different texts or situations together to look at what their intersection produces. Barad (2012) suggests that this methodology, this reading of one text through another or one situation through another can produce insights if the researcher

attentively and carefully [reads] for differences that matter in their fine details, together with the recognition that intrinsic to this analysis is an ethics that is not predicated on externality but rather entanglement. Diffractive readings bring inventive provocations; they are good to think with. (p. 2)

Like the fern's rhizomes, at this time of year, I am only beginning to grow my segmented research movement as a line of flight. I acknowledge that using a diffractive research methodology, for the most part, is an unpracticed approach for me-into new territory. Therefore, my aim is to simply chart what I learned by doing this exercise, identify what surprises me as Derrida (2000) might say, and recognize the differences of matter that matter, which according to Barad (2007) might build new insights. I begin by re-reading Derrida, Deleuze and Guattari together alongside the migratory non-human populations living close by who have become a part of me.

\footnotetext{
2 "A rhizome may be broken, shattered at a given spot, but it will start up again on one of its old lines, or on new lines. You can never get rid of ants because they form an animal rhizome that can rebound time and again after most of it has been destroyed. Every rhizome contains lines of segmentarity according to which it is stratified, territorialized, organized, signified, attributed, etc., as well as lines of deterritorialization down which it constantly flees. There is a rupture in the rhizome whenever segmentary lines explode into a line of flight, but the line of flight is part of the rhizome. These lines always tie back to one another. That is why one can never posit a dualism or a dichotomy" (Delueze \& Guattari, 1987, p. 9).

Cultural and Pedagogical Inquiry, Fall 2020, 12(2), pp. 107-118

ISSN 1916-3460 (C) 2020 University of Alberta

http://ejournals.library.ualberta.ca/index.php/cpi/index
} 
My lines of flight (point-to-point movements) during this exercise are not entirely through what Deleuze and Guattari call nomadic "smooth spaces."3 Mine are still the bumpy flights that cross over the roots and rocks of academic striations, that touchdown often to rethink, and stopover in unfamiliar places where I need to carefully reconsider. These touchdowns and stopovers are where, in my exercise, I try to understand with Derrida, Deleuze and Guattari how to conceptualize home as intersecting planes and thresholds, and what it means for (non)human nomads (migratory birds) to be war machines (engines of thought that disrupt conventional notions of the non-human and of hospitality). I also try to separate out notions of non-human migration being more related to survival and human migration being more related to politics, which is generally the accepted view, but in truth I was unable to do so. I found that politics and survival are hopelessly entangled in both human and non-human migrations. Human migrations are often directly related to survival (think Syrian refugees). Non-human migrations can be linked to the politics around emissions control, government denials of global warming, and the lack of deforestation regulations, to name but a few.

During two stopovers, I found myself thinking differently from Derrida, Deleuze and Guattari, and pursued two tangential lines of thought/flight as a result. First, I took a closer look at welcoming and came to see it as a site of opening that is not unlike reading a book or listening to a story. Second, I took a longer look at migration, imagining it as a point of view or a perspective as in a painting. Of course, I considered the perspective of the migrating ones who de-territorialize to a somewhere else and the perspective of the populations left in place who hold open in some form of migratory memory the expectation of return/re-territorialization. However, these perspectives assume a point of view of "who" and "when," but not "where." "Where" frames migration differently; it outlines the borders of a bird's territory and describes where it lives. From this perspective, a bird's territory can be seen to include its migratory endpoints and all the points in between. Understood this way, the concept of migration began to transform for me and become something very different. I discuss this and other touchdowns and stopovers in the coming sections but first I consider non-human hospitality.

\section{Non-human Hospitality}

I am not certain if Derrida (2000) thought that animals and plants were capable of hospitality. In Of Hospitality, and in response to Derrida's work, Anne Dufourmantelle (2000), suggests, "Human beings offer hospitality only to other human beings" (p. 136) and attributes this quotation to Derrida. However, this statement can be read in two ways. In one possible reading, Derrida could be saying that only humans can express hospitality, but in another possible reading he could be saying that humans do not extend hospitality to animals but could and perhaps should (Derrida \& Wills, 2002). Derrida (2002) is, at the very least, sensitive to the animal returning his gaze but does this mean he thinks they are capable of hospitality? I interpret what he refers to as a "crazy project [of his] of constituting everything [he has ever] thought or written within a zoosphere, the dream of an absolute hospitality and an infinite appropriation" to mean just that (p. 405). I further support this belief through Derrida's $(1998,2000)$ writings on Emmanuel Levinas and Levinas' conception of ethics as hospitality.

\footnotetext{
3 "nomad science and the war machine, on the other hand, consists in being distributed by turbulence across a smooth space, in producing a movement that holds space and simultaneously affects all of its points, instead of being held by space in a local movement from one specified point to another" (Deleuze \& Guattari, 1987, p. 363). Cultural and Pedagogical Inquiry, Fall 2020, 12(2), pp. 107-118 ISSN 1916-3460 @ 2020 University of Alberta http://ejournals.library.ualberta.ca/index.php/cpi/index
} 
Derrida (2002) seems to develop the idea of an ethical connection between hospitality and animals in The Animal That Therefore I Am (More to Follow). As a devoted student of Levinas, he clearly adopted his mentor's understanding of hospitality as evident in Adieu a Emmanuel Levinas (1998) and later in Of Hospitality (2000). There are two aspects of Levinas' concept of hospitality that Derrida (1998) applies to animals. The first, is the idea of the returned gaze of the other, and the second is the reflection of self in the face/eyes of the other. Related to the first, Derrida (2002) asks if "the naked truth of every gaze, given that that truth allows me to see and be seen through the eyes of the other, in the seeing and not just seen eyes of the other" (p. 383) does not also apply to animals? Related to the second point, he asks if "this cat [can] also be, deep within her eyes, my primary mirror" (Derrida \& Wills, 2002, p. 418)?

Derrida and Wills (2002) remind us that this kind of exchange with animals rarely happens, even with "people who have no doubt seen, observed, analyzed, reflected on the animal, but who have never been seen by the animal [because] their gaze has never intersected with that of an animal directed at them" (p. 382). In many ways, animals are construed and dismissed by humans as foreign (and lesser) others; human immigrants are also often treated as foreign (and lesser) others, not by animals but by other humans for this same reason: the directed gaze does not see the returned gaze of the other. However, when human eyes attend to (see) the foreign other and recognize that they too are being simultaneously seen and evaluated, a more equitable power dynamic has the possibility of emerging between them, be it between human and human or animal and human. Levinas calls this moment of mutual recognition, an ethical encounter; Derrida calls it an aporia. In such exchanges, there is an acknowledgement that mutual recognition is now part of what defines the other (Derrida, 1998; Raffoul, 1998).

I'm certain it happens instinctively between animals when they encounter unknown others - foreigners - in the woods. They size each other up and evaluate the other as a potential threat or as potential dinner. It would be folly not to do so. I've even seen it happen between a dog and a fox, and between myself and some animals. For now, I say only that I have met a number of "wild" animals. I speak specifically of recent engagements with a fox at three meters, with a hummingbird at less than a meter, and with a deer at about 10 meters and others during which we stopped our busy-ness and shared a nice long look with each other.

At the risk of sounding silly, each exchange I had with these non-humans resembled some of the exchanges I had with my human neighbors when I first moved here. We would bump into each other for the first time at the post box or on the street and they would acknowledge my recent arrival and point out their house to me; I would say something like "Hello, it's good to meet you," in French and then we'd chat. Thus, we began our process of mutual recognition.

\section{Foreigners or Guests?}

Such encounters with both my human and non-human neighbors were exchanges of recognition and in that moment, unconditional acceptance, because their acknowledgement of me and welcome ${ }^{4}$ came before getting to know me, or even knowing my name (Derrida \&

\footnotetext{
${ }^{4}$ Did my more-than-human neighbors actually welcome me? Not in so many words; in fact not with any words, but they did not attack me, nor did they run/fly away in fear. This seemed to me a hospitable welcome. The non-verbal exchanges on their part seemed to communicate something like this to me: "Ok, that's who you are, got it. That's where you live, got it. I'm around."

Cultural and Pedagogical Inquiry, Fall 2020, 12(2), pp. 107-118

ISSN 1916-3460 @ 2020 University of Alberta

http://ejournals.library.ualberta.ca/index.php/cpi/index
} 
Dufourmantelle, 2000). In this sense, according to Derrida (2002), they extended unconditional hospitality to me. Whereas Derrida (2002) might understand my role in these exchanges as a guest, and to some extent I agree with him, I felt that their acceptance of me was as a foreigner, as someone new and different who was expected would stay, not as a guest who they expected to might stay awhile and then go home. For this reason, I prefer to call Derrida's aporia in this context, a host-foreigner aporia.

Further, while my understanding of aporia accepts Derrida's definition as mutual recognition, acceptance, and embodiment of the other in a specific moment, a host-foreigner aporia also includes a temporal dimension. This dimension is a condition of doubt held in abeyance for an unspecified time. It is a waiting room of sorts. It is expressed as a suspension of disbelief that my difference or foreignness poses a threat. This condition is similar to how humans might experience a story, the host/reader offers the foreigner/author a willing suspension of disbelief ${ }^{5}$ in a storied place that can accommodate and acculturate both. In the forest, or on my street this willing suspension of disbelief took the form of a grace period during which my differences were acknowledged and accepted without being regarded as threatening. Had my neighbors been inhospitable, they would have never seen my returned gaze, and I would not have openly accepted me as different in the moment of our meeting, nor would I have been offered their unearned suspension of disbelief in me as a threat.

\section{Is Host a Problematic Term Too?}

I've heard that mother bears are inhospitable when their cubs are young (Stirling \& Barcus, 2016), yet some bears, especially in areas where human contact has been minimal, do offer humans hospitality even friendship (Genzlinger, 2018). Some animals ask for hospitality too. A robin couple, last year, built a nest, next to my front door just behind the porch light. I admit, in my human arrogance, I tried to discourage it, knowing there would be foot traffic that would not be good for any future chicks. So, I sat outside by the door so the pair would not come close and I dismantled the beginnings of their nest. After a couple of hours of sitting there, I got cold and went inside. No sooner did I go in, did their nest building activities resume. They built the nest and the female laid three eggs; two hatched and the family lived there for about a month. My son and I stopped using the front door during that time, and we installed a chain across the walkway to prevent others from coming too close.

As a host, I recognized the robins as foreigners who didn't quite belong in a place that was mine. As hosts, my human neighbors recognized me an English foreigner who didn't quite belong in a French community but none-the-less had a right to be there based on my ability and desire to buy a house there. There are three points to make at this juncture about the concepts of host, foreigner and guest: 1) the concept of host entails a notion of ownership, 2) the concept of foreigner describes a perception of difference always associated with first contact and that may persist long-term, and 3) the concept of guest implies welcome for the transient by a host that remains a temporary welcome for one who is on the move.

In practical terms, my neighbors collectively recognized me as linguistically foreign but seemed to take a wait-and-see attitude towards me anyway. As a newcomer to the community, I considered myself a guest in their society, a state I hoped would change once I got to know them

\footnotetext{
${ }^{5}$ Whether it is belief or disbelief depends on the prevailing beliefs or knowledges.

Cultural and Pedagogical Inquiry, Fall 2020, 12(2), pp. 107-118

ISSN 1916-3460 (C) 2020 University of Alberta

http://ejournals.library.ualberta.ca/index.php/cpi/index
} 
and they got to know me, even though legally I had every right to be there. As a newcomer to the more-than-humans, I often wondered what they thought of me. They too, I think, didn't regard me as much of a threat and perhaps not even as a foreigner. This is a point I will take up later. Perhaps, the robins even chose their nesting spot consciously having first observed me for a time. For my part, I am quite certain that humans, animals and birds can extend and appreciate hospitality.

\section{More-than-Human Nomads and War Machines}

A nomad is, for Delueze and Guattari (1987), a "being that resists the hierarchy of centralization" (University of Texas, 2014, p. 2). Nomadology is "the opposite of a history" (Deleuze \& Guattari, 1987, p. 23). The war machine is an assemblage of thoughts and conditions used by nomads to oppose "the State apparatus" and to make "thought itself nomadic" (p. 25). Non-human beings may be understood as nomadic by this definition because even the most domesticated ones resist anthropocentric rules and modes of being.

Weeds continue to grow where humans don't want them to, foxes come into towns when hungry, insects continue to feed on us and enter our homes in defiance of the apparatuses constructed by humans. Nomadic thought also applies to migratory non-humans in so much as it is understood as a concept in "its unrestrained usage [to be] a set of circumstances, at a volatile juncture. It is a vector: the point of application of a force moving through a space at a given velocity in a given direction. The concept has no subject or object other than itself. It is an act" (Deleuze \& Guattari, 1987, p. xiii). As far as human understanding is concerned, nomadic thought is en-act-ed exactly like this every time the Canada Geese takeoff at daybreak. These migratory birds self-organize for takeoff as an assemblage, not only in concert with each other but with the time of day, the time of year, and a migratory pull that launches them upward and toward a different place. ${ }^{6}$

Derrida (2000) takes up the concept of nomad differently from Delueze and Guattari (1987) seeing it as a presentation of difference, strangeness, or foreignness in a fixed moment in a fixed place before a fixed other. It is this presentation of difference/foreignness that Derrida (1974) understands as the necessary precondition for the operation of hospitality, a hospitality that when extended is based on an aporia of recognition, acceptance, and embodiment of the other.

While human immigrants may be considered both foreigners and nomads, it seems counterintuitive to consider them "war machines" even in the Deleuzian sense because they are less an instrument of war than a consequence of it. They are figured as war machines who threaten Americans life and American culture by the current American president and his supporters (and sometimes called animals), ${ }^{7}$ and viewed negatively by many in that country. However, Deleuze and Guattari (1987) did not consider war machines as negative forces; to the contrary, they considered them positive forces of change. Immigrants, as Deleuzian war machines, carry and embody different ways of thinking that are necessary for challenging the status quo, because it "is

\footnotetext{
${ }^{6}$ Playing poetically with the biblical image of a camel passing through the eye of a needle, I wonder if it is perhaps harder for humans to become nomads than it is for non-humans.

${ }^{7}$ I object to the use of the term animal in this way for many reasons. First, the people using the term this way, mean for it to be derogatory. Second it assumes an anthropocentric and Humanistic view of humans is understood. Third, I've never encountered an animal that is truly malevolent, but sadly, I can't say that about all humans.
}

Cultural and Pedagogical Inquiry, Fall 2020, 12(2), pp. 107-118

ISSN 1916-3460 () 2020 University of Alberta

http://ejournals.library.ualberta.ca/index.php/cpi/index 
often the Foreigner (xenos) who questions... [who] carries and puts the question" to society, without necessarily asking society a question (Derrida \& Dufourmantelle, 2000, p. 5). By this I mean, it is the foreigner or immigrant who is the one who asks questions about local practices and who is the one who brings those automatically performed practices of society to society's consciousness again, where they might be examined or questioned. However, the most significant question the foreigner asks is a non-verbal one marked by his or her mere presence; it is a question of do you see me, accept me, do you see me looking back at you and do you want me to accept you too?

Migratory birds carry similar questions for both human and non-human populations. They carry questions about where they have been and how life is different in a foreign place. Their droppings carried and left enroute are the traces of such questions being answered. Migratory birds, like human foreigners, are often seen as an undifferentiated group or mass without subjectivity. They are not seen in their varied and differentiated forms thus making them easy beings to objectify. Derrida (2002) suggests that "[a]mong non-humans and separate from non-humans there is an immense multiplicity of other living things that cannot in any way be homogenized, except by means of violence and willful ignorance, within the category of what is called the animal or animality in general" by humans (pp. 415-416).

Holding this thought concerning the "violence and willful ignorance" of humans towards "animals," I see another parallel with Deleuze and Guattari's (1987) concept of a war machine. The regular (mechanistic) departures and returns of migratory birds that signal seasonal changes for humans also makes them look up to watch the flight of these birds; to notice them. Holding a human's attention, if only for a moment, may be interpreted as an act of resistance (a war) that seeks human acknowledgement of the returned gaze of birds; to see them as they look down when humans look up.

Seeing the returned gaze of the other, particularly that of the animal is a key concept for Derrida (2002) and is, as I see it, the beginning of hospitality. A host may invite a foreigner in, but it is only when the foreigner and the host begin to see the returned gaze of each other, that a more permanent relationship is possible and the monikers of host and foreigner/guest begin to dissolve. However, it is the war machine ${ }^{8}$ as an assemblage of forces unrestricted by the mores and rules of society that may well be the only mechanism that can disrupt or "worry" humans enough, as Derrida (2002) says, into a different kind of ethical/hospitable relationship with birds, animals, and human, others considered foreign (p. 393).

In some ways, migratory birds are a good metaphor/mechanism for thinking about the violence/war humans wage on animals and other non-human and human foreigners, because migratory birds flagrantly defy human political borders crossing them at will and because they are often figured as projectiles or as dangerous nomadic hordes (murmurations). ${ }^{9}$

\footnotetext{
${ }^{8}$ I always imagine this as a trebuchet.

${ }^{9}$ March 25, 2020, I witnessed the murmuration of about a 1000 first-year male waxed winged blackbirds before they settled in the arbor just behind my house. See https://www.al.com/living/2017/02/blackbird murmurations explain.html Cultural and Pedagogical Inquiry, Fall 2020, 12(2), pp. 107-118 ISSN 1916-3460 (C) 2020 University of Alberta http://ejournals.library.ualberta.ca/index.php/cpi/index
} 


\section{Where are the Territorial Borders?}

Scale is a significant factor in discussions of non-human territory and borders. There are several kinds of borders, in nature, each with its own scale. One kind of territorial border is enacted by birds and some animals of the same species at a micro-level to ensure a fair distribution of food and resources (Potts \& Lewis, 2014). There is another kind of territorial boundary that delineates the area occupied by a species on a larger scale. There is a different kind of territory specific to migratory birds that is commonly understood to be composed of two territories - two where(s) and a flyway that connects them. I want to touch down here to think about migratory territory from a slightly different perspective, not as a local micro-feeding territory, nor as the two areas occupied by a bird species surrounding the endpoints of a migratory here or there, but as a single migratory territory encompassing both endpoints and all of the territory in between.

Seen from this perspective, the territory of each migratory bird is much larger and of a different scale. The territory that encompasses breeding and non-breeding territories, plus a flyway, looks like a plane instead of as a bidirectional line from point A to point B. Imagine this plane superimposed over a map together with all the other planes that represent all the other bird species occupying the territory represented by the map. What one would see is many overlapping oval areas covering a shared territory. These areas are what Deleuze and Guattari (1987) describe as planes (of consistency) that are made up of "distinct but entangled lines" of flight (p. 3). Deleuze and Guattari (1987) describe the plane of "consistency of Nature" as an abstract machine with

pieces [that] are the various assemblages and individuals, each of which groups together... an infinity of more or less interconnected relations. There is... a unity to the plane of nature, which applies equally to the inanimate and the animate, the artificial and the natural. (p. 254)

On the plane of nature, migratory bird species may be understood to have relations and claim to the whole territory that they inhabit on the ground or above it which they share with others. In another sense, they can be understood as being claimed by the territory too because of their entanglements with it through interactions with the other beings, animate or inanimate living there. $^{10}$

Above this territory, while flying in what Deleuze and Guattari (1987) call smooth space, migratory birds traverse, "a field without conduits or channels" (p. 371). Even though they organize in specific ways and travel along preferred routes, their flight in space is unpredictable. It can, however, be disrupted by air flows and turbulences that influence trajectories, requiring migratory birds to find unique and creative ways of dealing with "course," fatigue, and food along the way in response to the conditions presented. These turbulences and intensities in smooth space give rise to migratory birds forming more connections with the territory below; connections that forge claims by them and forge claims to them by the territory.

This reciprocal claim of migratory birds and territory suggests that the territory they occupy is an inclusive space because it is shared with multiple others, each with similar claims. It

\footnotetext{
${ }^{10}$ Deterritorialization is conceptualized differently on a plane than it is as a line or from a point. It involves nomadic movement as flight through smooth space. See Delueze and Guattari, 1987, pp. 381-82, for a description of this point. Cultural and Pedagogical Inquiry, Fall 2020, 12(2), pp. 107-118 ISSN 1916-3460 () 2020 University of Alberta http://ejournals.library.ualberta.ca/index.php/cpi/index
} 
connects with Derrida's (2000) idea of hospitality through recognition and acceptance of difference but it challenges notions of both the guest and the foreigner at the same time. How can something that claims and is claimed by a host territory be a guest or a foreigner on it or to it? It seems to me that an inclusive space precludes, by definition, the foreigner or the guest because all present are assumed to belong. Following this line of thought, is it reasonable to ask if the aporia Derrida speaks of applies to be something more than a host-guest or host-foreigner enactment? Does it rather apply in the natural world to enactments between a territory and all the living beings on it? If true, does it follow that all beings who can sustain themselves in a place belong to it defacto? In the natural world, it seems to me to be the case. Only in exclusionary spaces with well-defined borders that mark property ownership or spaces with well-defined practices that act as cultural borders, can a foreigner exist (Derrida \& Dufourmantelle, 2000). And, no question, where strangers/foreigners exist, hospitality can be offered to foreigners and to guests, but this does not seem to be the way of nature. Natural hospitality seems to be about acknowledgement of the other's gaze and a mutual acceptance of difference in a common inclusive place. ${ }^{11}$ I observe here that such hospitality seems to be offered by non-human animals, but not offered, as readily, by humans to other human animals, and often not offered at all by human animals to non-human animals.

\section{Territory as a Breathing Organism}

For me, perhaps the most interesting aspect of considering migratory bird territory as a single wide area plane covering all the movements of a migratory bird species, is a liveliness that comes into being. On such a plane, migration no longer needs to be understood as two separate movements. It can be understood as two parts of a single movement, like a single breath, that consists of an inhalation and an exhalation, or as a heartbeat pumping in and pumping out. With this simple shift in perspective, the whole migratory area begins to pulse - to take on a poetic rhythm or music. It ceases to be just territory and becomes a material organism, alive and vibrant. Like any organism, a territory's liveliness constitutes and is constituted by the inter/intra-actions and memories of its members, not only by the haptic breath memory of the migratory birds, but by the memories of trees, rocks and other animals, each created in part by mutual recognition between beings in various assemblages with the territory (Latour, 2004).

Trees form the tall leafy kinship memories of their cooperative relationships with birds, as well as the learned memory that they transfer chemically as knowledge (about the birds), to healthy members of their species before dying (Beiler et al., 2015; Simard, 2016). Non-migratory birds, such as crows, embody the vigilant memories that protect migratory birds by warning them of predacious threats. ${ }^{12}$ Rocks form the long, stratified memories marked recently by the Anthropocene (Waters et al., 2016). While Deleuze and Guattari (1987) might disagree with the importance I assign to trees, preferring a rhizome metaphor to disrupt certain cultural notions of their time, I argue that trees are important to birds and therefore to my exercise. ${ }^{13}$

\footnotetext{
${ }^{11}$ For humans this is akin to the affect Louis Armstrong sings about in A Wonderful World, https://www.google.com/search?q=louis+armstrong\%2C+a+beautiful+world\&oq=louis+armstrong\%2C+a+beautiful +world\&aqs=chrome..69i57.18616j0j7\&sourceid=chrome\&ie=UTF-8

${ }^{12}$ Crows also have incredible organizational memories. I've witnessed their coordinated alarms and belligerent escorts of foxes and owls out of a territory that might have otherwise endangered the young of the place.

13 Mycelium acts as a kind of connective tissue between trees which might be construed as rhizome-like behavior.

Cultural and Pedagogical Inquiry, Fall 2020, 12(2), pp. 107-118

ISSN 1916-3460 (C) 2020 University of Alberta

http://ejournals.library.ualberta.ca/index.php/cpi/index
} 


\section{Territory as Home and Host}

If hospitality for Derrida (2000) is primarily a question of where (and for whom), for Deleuze and Guattari (1987), hospitality is found no-where in A Thousand Plateaus. However, the authors do discuss the term "territory" at length, which for this exercise, I equate with "where." For humans, home is usually where hospitality is offered. Ordinarily, it is at the threshold of the house, the physical structure of intersecting vertical and horizontal planes that we call home or "our place." The threshold of our home is in fact the only place, as private citizens, we can normatively offer hospitality because beyond the threshold, inside the house, is an exclusive space conceived as belonging to (or owned by) the dweller. In a similar way, a public official may offer hospitality from the threshold of a town, or a province, or a country for the same reasons of ownership. However, between species of animals and birds, no similar single point of entry or threshold exists or operates. ${ }^{14}$ When species meet (Haraway, 2010), the place of encounter for both is always in one's own territory (unless the unfortunate birds or animals are confined by a paddock or zoo, etc.) but almost never near, let alone at, the entrance to its dwelling place - its home. Based on personal experience, animals and birds do not ordinarily engage with others close to their homes.

However, when species meet in their natural shared territory, they look at each other and recognize that the other is also looking back, sizing him/her up, and evaluating the being as a potential threat or dinner. Not to recognize the other doing this would not only be imprudent, but it would also be, for lack of a better word, disrespectful of the other's right to be where they are. This is very unlike the engagement that happens between humans at the threshold of a home where hospitality may be offered or denied to "all the living things that man does not recognize as his fellows, his neighbors, or his brothers" (Derrida \& Wills, 2002, p. 402).

\section{Summing Up}

I set out to look at bird migrations, through a lens of hospitality, as described by Derrida (2000) and territory as described by Deleuze and Guattari (1987) using a diffractive methodology (Barad, 2012) of reading Derrida (1998, 2000, 2002), and Deleuze and Guattari (1987) through each other. I wondered if hospitality rested solely on the host-guest aporia and decided at first that it rested more accurately on the host-foreigner aporia as this could operate outside the implied boundaries of ownership where host-owned and guest did not, and outside the sense of temporary residence implied by the term guest. I turned to Deleuze and Guattari to understand the term host as inhabitants, be they nomad or territorialized. For migratory birds that winter in one location and summer in another, thinking about territorial boundaries ended with my thinking that territory itself was the vital host. I came to realize that territory in the morethan-human world is the host that connects with all that live in a place. It is territory that mediates an entangled web of connections between all the other beings that find themselves in a place. And it is as host that territory creates an inclusive sense of belonging for all the beings who reside there. In concluding that territory is the natural host in the more-than-human world, I began to see how my host-foreigner construction was faulty. I reasoned that the concept of foreigner could not be reconciled with the concept of inclusivity. I replaced the concept of

\footnotetext{
${ }^{14}$ For animals and birds of the same species, the perimeter of a micro feeding territory could be construed as kind of threshold.

Cultural and Pedagogical Inquiry, Fall 2020, 12(2), pp. 107-118

ISSN 1916-3460 () 2020 University of Alberta

http://ejournals.library.ualberta.ca/index.php/cpi/index
} 
foreigner with the concept of differentiated being and ended up thinking that territorydifferentiate being was the natural equivalent of the host-guest aporia that underwrote hospitality in the natural world.

I wonder, now that I approach the end of my diffractive thinking exercise, what kind of place we humans would live in with each other and with our more-than-human neighbors, if we extended hospitality like animals and birds seem to do-as a recognition of difference between beings on a shared territory that pulses with life and mediates inclusive belonging? Would we act differently, when we find ourselves in a place (a where) looking at the strangeness of another? Would we first acknowledge that the other is gazing back, not only assessing us as we assess them, but seeing who and what we are as different from them? Would we still objectify the immigrant, the homeless, and all the others we think of as strangers, or would that look that saw the other looking back at us change what we see? Would we humans be inclined to make room for the other, hold a place open for them while they are gone or not yet arrived, like the forest and animals do for migratory birds? Could we conceive of our private homes as a shared place? Could we conceive of our planet as a shared home and a place where we all have claim to a poetry of belonging through an ethics as hospitality?

Note: This article is funded by a grant from the Social Sciences and Humanities Research Council (SSHRC) and by a scholarship through Ontario Graduate Scholarships (OGS). 


\section{References}

Barad, K. M. (2007). Meeting the universe halfway: Quantum physics and the entanglement of matter and meaning. Durham and London: Duke University Press.

Barad, K. M. (2012). Matter feels, converses, suffers, desires, yearns and remembers. In R. Dolphijn \& I. VanderTuin (Eds.), New materialism: Interviews and cartographies. Ann Arbor: Open Humanities Press, MPublishing.

Beiler, K. J., Simard, S. W., \& Durall, D. M. (2015). Topology of tree-mycorrhizal fungus interaction networks in xeric and mesic Douglas-fir forests. Journal of Ecology, 103(3), 616-628. https://doi.org/10.1111/1365-2745.12387

Deleuze, G., \& Guattari, F. (1987). A thousand plateaus: Capitalism and schizophrenia (B. Massumi, Ed.). Minneapolis: University of Minnesota Press.

Derrida, J. (1998). From Adieu à Emmanuel Levinas. Research in Phenomenology, 28(1), 20-36. https://doi.org/10.1163/156916498X00029

Derrida, J., \& Dufourmantelle, A. (2000). Of hospitality. Cultural memory of the present. Stanford, Calif.: Stanford University Press.

Derrida, J., \& Spivak, G. C. (1974). Of grammatology. Baltimore: The Johns Hopkins University Press.

Derrida, J., \& Wills, D. (2002). The Animal That Therefore I Am (More to Follow). Critical Inquiry, 28(2), 369-418.

Genzlinger, N. (2018, May 10). Charlie Russell, Who Befriended Bears, Dies at 76. New York Times.

Haraway, D. (2010). When species meet: Staying with the trouble. Environment and Planning D: Society and Space, 28(1), 53-55. https://doi.org/10.1068/d2706wsh

Latour, B. (2004). Why political ecology has to let go of nature. In Politics of Nature: How to Bring the Sciences into Democracy (pp. 9-52). Harvard University Press.

Potts, J. R., \& Lewis, M. A. (2014). How do animal territories form and change? Lessons from 20 years of mechanistic modelling. Proceedings. Biological Sciences, 281(1784), 2014.0231.

https://doi.org/10.1098/rspb.2014.0231

Raffoul, F. (1998). On Hospitality, between Ethics and Politics. Research in Phenomenology, 28(1), 274283. https://doi.org/10.1163/156916498X00164

Simard, S. (2016, August 30). How trees talk with each other (TED Talk). Retrieved from: https://www.youtube.com/watch?v=Un2yBgIAxYs

Stirling, I., \& Barcus, C. U. (2016). Exploring the Natural History of Polar Bears. National Geographic Society.

University of Texas, A. (2014). Nomadology. Texas Theory Wiki.

Waters, C. N., Zalasiewicz, J., Summerhayes, C., Barnosky, A. D., Poirier, C., Galuszka, A., ... Wolfe, A. P. (2016). The Anthropocene is functionally and stratigraphically distinct from the Holocene. Science, 351(6269), aad2622-aad2622. Retrieved from: https://doi.org/10.1126/science.aad2622

Cultural and Pedagogical Inquiry, Fall 2020, 12(2), pp. 107-118

ISSN 1916-3460 () 2020 University of Alberta

http://ejournals.library.ualberta.ca/index.php/cpi/index 